\title{
17- $\beta$-Estradiol Counteracts the Effects of High Frequency Electromagnetic Fields on Trophoblastic Connexins and Integrins
}

\author{
Franco Cervellati, ${ }^{1}$ Giuseppe Valacchi, ${ }^{1,2}$ Laura Lunghi, ${ }^{1}$ Elena Fabbri, ${ }^{3}$ Paola Valbonesi, ${ }^{3}$ \\ Roberto Marci, ${ }^{4}$ Carla Biondi, ${ }^{1}$ and Fortunato Vesce ${ }^{4}$ \\ ${ }^{1}$ Department of Life Science and Biotechnology, Section of General Physiology, University of Ferrara, \\ Via L. Borsari 46, 44121 Ferrara, Italy \\ ${ }^{2}$ Department of Food and Nutrition, Kyung Hee University, 1 Hoegi-dong, Dongdaemun-gu, Seoul 130-701, Republic of Korea \\ ${ }^{3}$ Interdepartmental Centre for Environmental Science Research, University of Bologna, Ravenna, Italy \\ ${ }^{4}$ Department of Biomedical Sciences and Advanced Therapy, Section of Obstetrics and Gynaecology, \\ University of Ferrara, Ferrara, Italy \\ Correspondence should be addressed to Franco Cervellati; franco.cervellati@unife.it
}

Received 18 February 2013; Accepted 11 May 2013

Academic Editor: Chiara De Luca

Copyright ( $\odot 2013$ Franco Cervellati et al. This is an open access article distributed under the Creative Commons Attribution License, which permits unrestricted use, distribution, and reproduction in any medium, provided the original work is properly cited.

\begin{abstract}
We investigated the effect of high-frequency electromagnetic fields (HF-EMFs) and 17- $\beta$-estradiol on connexins (Cxs), integrins (Ints), and estrogen receptor (ER) expression, as well as on ultrastructure of trophoblast-derived HTR-8/SVneo cells. HF-EMF, $17-\beta$-estradiol, and their combination induced an increase of $\mathrm{Cx} 40$ and $\mathrm{Cx} 43 \mathrm{mRNA}$ expression. HF-EMF decreased Int alphal and $\beta 1$ mRNA levels but enhanced Int alpha 5 mRNA expression. All the Ints mRNA expressions were increased by $17-\beta$-estradiol and exposure to both stimuli. ER- $\beta$ mRNA was reduced by HF-EMF but augmented by $17-\beta$-estradiol alone or with HF-EMF. ER- $\beta$ immunofluorescence showed a cytoplasmic localization in sham and HF-EMF exposed cells which became nuclear after treatment with hormone or both stimuli. Electron microscopy evidenced a loss of cellular contact in exposed cells which appeared counteracted by $17-\beta$-estradiol. We demonstrate that $17-\beta$-estradiol modulates Cxs and Ints as well as ER- $\beta$ expression induced by HF-EMF, suggesting an influence of both stimuli on trophoblast differentiation and migration.
\end{abstract}

\section{Introduction}

Broadcasting systems and mobile phones generate highfrequency electromagnetic fields (HF-EMFs) ranging from $30 \mathrm{kHz}$ to $300 \mathrm{GHz}$. As a consequence of their widely increasing diffusion human beings are today chronically exposed to such sources of energy, whose influences on physiological responses have not been yet exhaustively investigated. Data regarding the effects of these fields on human health are conflicting $[1,2]$. Interestingly, in vivo human evaluation of brain glucose metabolism showed a significant increase upon acute cell phone radiofrequency signal exposure $[3,4]$.

As far as reproductive function is concerned, based on postnatal evaluation, no significant increase of reproductive risk was found in the rat following irradiation $[5,6]$. However, a decrease in the number of mouse offspring, a prevalence of males over females, and an increase of stillbirth were also reported [7]. More recently it has been reported that the use of mobile phone decreases the human sperm count, motility, viability, and normal morphology $[8,9]$ probably due to oxidative stress [10].

During the first trimester of human pregnancy, extravillous trophoblast (EVT) cells invade the uterine spiral arteries generating a low-resistance, high-capacity uteroplacental circulation that ensures the success of gestation [11]. EVT cell functions are tightly regulated by multiple factors such as gapjunctional intercellular communication (GJIC) [12-14] and integrins $[15,16]$.

Gap junctions are membrane channels constituted by the association of two hemi-channels, termed connexons, 
each composed of six connexin (Cx) subunits. Gap junctions provide not only a pathway for the exchange of signaling molecules, but they are recognized as true signaling complexes regulating cell function and transformation [17]. Indeed, Cxs influence cell growth, development, and differentiation both in normal and pathologic conditions [17].

Integrins (Ints) are heterophilic cell adhesion molecules consisting of noncovalently connected $\alpha$ and $\beta$ chains that together determine ligand-binding specificity and intracellular coupling. Thereby, Ints are the most important cell surface receptors for cell interactions with the extracellular matrix structures [18].

Changes in both Cxs and Ints $[13,16,19,20]$ expression have been reported during trophoblast differentiation to EVT.

Environmental stresses, including chemical pollutants [21], ionizing radiations [22], and oxidative stress [23], influence the expression of both Cxs and Ints. Moreover it is well documented that, in trophoblast tissue, the expression of these adhesion molecules is modulated by several hormones including estradiol $[15,24,25]$. This growth-promoting hormone affects placental function and embryo development both in primates and humans [26]. In addition it has been found to be involved in cytotrophoblast cell differentiation towards syncytiotrophoblast [26-29].

On the other hand, clinical effects of HF-EMF exposure on pregnancy are likely to occur, since it has been demonstrated that it results in increased levels of heat-shock protein 70 (HSP 70) in human amnion cells in vitro [30], although it does not influence the expression of this protein in human first-trimester extravillous-derived HTR-8/SVneo cells [31]. This cell line, derived from first-trimester human EVT, preserves all of their parental markers, as well as their responsiveness toward factors known to control EVT cell functions [32], thus representing a suitable model for the experimental study of early placentation process. In this experimental model we have shown that one hour exposure to GSM-217 Hz signals selectively modifies Cx mRNA expression pattern and protein localization [33].

The aim of the present work was to investigate whether HF-EMFs and 17- $\beta$-estradiol regulate cell-cell and cellextracellular matrix interactions. To answer this question, we analyzed the effect of HF-EMFs, $17-\beta$-estradiol, and their combination on both $\mathrm{Cx}$ and Int expressions inHTR-8/SVneo cells. Moreover, we studied the effect of HF-EMFs, 17- $\beta$ estradiol, and their combination on the estrogen receptor expression and immunofluorescence localization. Under the same experimental conditions, ultrastructural features were also evaluated.

\section{Materials and Methods}

2.1. Cell Cultures. The HTR-8/SVneo cell line was kindly provided by Doctor CH Graham of Queen's University, Kingston, ON, Canada. Cells were grown in RPMI 1640 medium supplemented with $10 \%$ fetal bovine serum, $2 \mathrm{mM} \mathrm{L-}$ glutamine, $100 \mathrm{U} / \mathrm{mL}$ penicillin, and $100 \mu \mathrm{g} / \mathrm{mL}$ streptomycin (Invitrogen Paisley, Scotland, UK). Cells were maintained at $37^{\circ} \mathrm{C}$ in normal atmosphere containing $5 \% \mathrm{CO}_{2}$. For the experiments, cells were treated with trypsin, removed from culture flasks, and then seeded at a density of $1 \times 10^{6}$ cells per 35 mmdiameter Petri dish. After $24-48 \mathrm{~h}$ culture, semiconfluent monolayers were exposed to treatments.

2.2. Chorionic Villi. First-trimester human chorionic villi were obtained from consenting patients undergoing chorionic villous biopsy for prenatal diagnosis at the 11th week of gestation. Only tissues from physiological pregnancy were included in the study.

For RNA isolation, tissues were immediately frozen in liquid nitrogen and stored at $-80^{\circ} \mathrm{C}$.

2.3. Cell Viability Assay. Cell viability was assessed by MTT (3-(4,5 dimethylthiazol-2-yl)-2,5-diphenyl tetrazolium bromide; Sigma Chemical Co., St. Louis) assay in $0.01 \mathrm{M}$ phosphate-buffered saline ( $\mathrm{pH}$ 7.2). After $1 \mathrm{~h}$ cell incubation at $37^{\circ} \mathrm{C}$, the formazan formed was extracted in $1 \mathrm{~mL}$ of DMSO for $1 \mathrm{~h}$ at $37^{\circ} \mathrm{C}$ and its absorbance measured at $510 \mathrm{~nm}$ in a spectrophotometer against a DMSO blank. The mean absorbance values obtained from 3 replicates were compared with controls. Inhibition of the MTT reduction potential of the HTR-8/SVneo cells was calculated and expressed as a percentage of control values following the method described [35], data not shown.

2.4. HF-EFM Exposure. All experiments consisted of control samples kept at $37^{\circ} \mathrm{C}$ and $5 \% \mathrm{CO}_{2}$ in a Forma thermostat. Sham- and HF-EMF-exposed samples were kept in identical Forma thermostats which also housed the GSM-exposure system. Cells were exposed for $1 \mathrm{~h}$ to a $1.8 \mathrm{GHz}$ sinusoidal wave, whose amplitude was modulated by rectangular pulses with a repetition frequency of $217 \mathrm{~Hz}$ [36] applied at timeaveraged SAR values of $2 \mathrm{~W} / \mathrm{Kg} . \mathrm{s}$, the safety limit for mobile phone emission according to INCIRP (International Commission on Non-Ionizing Radiation Protection). The exposure system was developed and built by the Foundation for Research and Information Technologies in Society (IT'IS Foundation, Zurich, Switzerland) following the specifications outlined in 5 [36] and extensively described in [37]. The system consisted of two $128.5 \times 65 \times 424 \mathrm{~mm}^{3}$ brass singlemode waveguide resonators operated inside the Forma thermostat. Each resonator was equipped with a plastic holder hosting six $35 \mathrm{~mm}$ Petri dishes arranged in two stacks. The carrier frequency, modulation, SAR level, and the periodicallyrepeated on and off exposure times were controlled by a computer. The exposure/sham conditions were assigned to the two waveguides by the computer-controlled signal unit. All exposure conditions and monitor data were encrypted in a file, which was decoded only after data analysis in order to ensure blind conditions for the experiment. Dosimetric field and temperature probes ensured that the temperature differences between sham (cells incubated into the waveguide resonator not selected for irradiation) and exposed cells at the standard condition of incubation was less than $0.1^{\circ} \mathrm{C}$, ensuring no untoward thermal influence.

2.5. Estradiol Treatment. HTR-8/SVneo cells were treated for $24 \mathrm{~h}$ with $17-\beta$-estradiol (Sigma Chemical Co., St. Louis, $\mathrm{MO})$. Control and treated cells were maintained at $37^{\circ} \mathrm{C}$ by 
TABLE 1: Primer sequences and PCR condition.

\begin{tabular}{|c|c|c|c|c|c|c|}
\hline Gene & Primer sequence & ${ }^{T_{a}} \mathrm{C}$ & $\begin{array}{l}\text { Product } \\
\text { length } \\
\text { (bp) }\end{array}$ & $\begin{array}{c}\text { QPCR } \\
\text { amplification } \\
\text { efficiency } \\
(\%)\end{array}$ & No. of cycles & $\begin{array}{l}\text { Reference } \\
\text { primer } \\
\text { bank }\end{array}$ \\
\hline $\mathrm{Cx} 40$ & $\begin{array}{l}\text { F: } 5^{\prime} \text {-tcctggaggaagtacacaagc- } 3^{\prime} \\
\text { R: } 5^{\prime} \text {-atcacaccggaaatcagcctg- } 3^{\prime}\end{array}$ & 60.1 & 137 & 97.2 & 39 & $\begin{array}{c}\text { GenBank } \\
\text { Accession } \\
\text { NM } \\
181703\end{array}$ \\
\hline $\mathrm{Cx} 43$ & $\begin{array}{l}\text { F: } 5^{\prime} \text {-tcaagcctactcaactgctgg- } 3^{\prime} \\
\text { R: } 5^{\prime} \text {-tgttacaacgaaaggcagactg- } 3^{\prime}\end{array}$ & 60.4 & 125 & 98.4 & 39 & $\begin{array}{c}\text { GenBank } \\
\text { Accession } \\
\text { NM } \\
000165\end{array}$ \\
\hline $\mathrm{Cx} 45$ & $\begin{array}{l}\text { F: } 5^{\prime} \text {-atgagttggagctttctgactcg- } 3^{\prime} \\
\text { R: } 5^{\prime} \text {-cggctgttctgtgttgcac- } 3^{\prime}\end{array}$ & 60.4 & 174 & 94.5 & 39 & $\begin{array}{c}\text { GenBank } \\
\text { Accession } \\
\text { NM } \\
005497\end{array}$ \\
\hline Int $\alpha 1$ & $\begin{array}{l}\text { F: } 5^{\prime} \text {-tgctgctggctcctcactgttgtt- } 3^{\prime} \\
\text { R: } 5^{\prime} \text {-gggcccacaagccagaaatcct- } 3^{\prime}\end{array}$ & 60.6 & 354 & 95.8 & 39 & $\begin{array}{c}\text { GenBank } \\
\text { Accession } \\
\text { NM } \\
181501.1 \\
\end{array}$ \\
\hline Int $\alpha 5$ & $\begin{array}{l}\text { F: } 5^{\prime} \text {-gaaccagagccgectgctgg- } 3^{\prime} \\
\text { R: } 5^{\prime} \text {-gagcctccacggagagccga- } 3^{\prime}\end{array}$ & 60.8 & 215 & 95.8 & 39 & $\begin{array}{c}\text { GenBank } \\
\text { Accession } \\
\text { NM } \\
002205.2\end{array}$ \\
\hline Int $\beta 1$ & $\begin{array}{l}\text { F: } 5^{\prime} \text {-acgccgcgcggaaaagatgaatt- } 3^{\prime} \\
\text { R: } 5^{\prime} \text {-acccacaatttggccctgcttg- } 3^{\prime}\end{array}$ & 60.5 & 155 & 95.4 & 39 & $\begin{array}{c}\text { GenBank } \\
\text { Accession } \\
\text { NM } \\
002211.3\end{array}$ \\
\hline RPL13A & $\begin{array}{c}\text { F: } 5^{\prime} \text {-cctaagatgagcgcaagttgaa- } 3^{\prime} \\
\text { R: } 5^{\prime} \text {-ccacaggactagaacacctgctaa- } 3^{\prime}\end{array}$ & 60.2 & 203 & 97.3 & 39 & $\begin{array}{l}\text { Pattyn et al. } \\
2006[34]\end{array}$ \\
\hline RPL11A & $\begin{array}{l}\text { F: } 5^{\prime} \text {-tgcgggaacttcgcatccgc- } 3^{\prime} \\
\text { R: } 5^{\prime} \text {-gggtctgccctgtgagctgc- } 3^{\prime}\end{array}$ & 60.1 & 108 & 96.5 & 39 & $\begin{array}{c}\text { GenBank } \\
\text { Accession } \\
\text { NM } \\
000975.2 \\
\end{array}$ \\
\hline GAPDH & $\begin{array}{l}\text { F: } 5^{\prime} \text {-tgacgctggggctggcattg- } 3^{\prime} \\
\text { R: } 5^{\prime} \text {-ggctggtggtccaggggtct- } 3^{\prime}\end{array}$ & 60 & 134 & 94.6 & 39 & $\begin{array}{c}\text { GenBank } \\
\text { Accession } \\
\text { NM } \\
002046.3\end{array}$ \\
\hline
\end{tabular}

Data calculated by OpticonMonitor 3 Software (Bio-Rad).

Forma thermostat in normal atmosphere containing $5 \% \mathrm{CO}_{2}$ and stabilized in serum-free medium for $1 \mathrm{~h}$ before HF-EFM exposure. The optimal concentration of $10^{-6} \mathrm{M} 17-\beta$-estradiol was chosen on the basis of a dose-response curve carried out in preliminary experiments (data not shown).

2.6. $R T-q P C R$ (Reverse Transcription Quantitative Real-Time $P C R)$. Total RNA from $2 \times 106$ HTR-8/SVneo cells for each experimental condition was extracted with the AURUM total RNA Mini Kit with DNAse digestion (Bio-Rad, Laboratories, Inc., USA), according to the manufacturer's recommended procedure. After solubilization in RNAase-free water, total RNA was quantified by Bio-Rad SmartSpec Plus spectrophotometer (Bio-Rad, Laboratories, Inc., USA). First-strand cDNA was generated from $1 \mu \mathrm{g}$ of total RNA using iScript cDNA Synthesis Kit (Bio-Rad Laboratories, Inc., USA). As shown in Table 1, primer pairs were obtained from Primer Bank from the Real-Time PCR Primer and Probe Database,
RT primerDB [34], to hybridise to unique regions of the appropriate gene sequence. The reverse transcriptase (RT-) PCR reactions were carried out using $1 \mu \mathrm{L}$ of cDNA in a $15 \mu \mathrm{L}$ total volume of PCR buffer (Invitrogen, Milan, Italy), containing $3 \mathrm{mM} \mathrm{MgCl}, 300 \mu \mathrm{M}$ dNTPs, and $300 \mathrm{nM}$ of appropriate primers. Taq polymerase $(0.35 \mathrm{U})$ was also added. The amplification reactions were carried out in a thermal gradient cycler (Bio-Rad Laboratories, Inc., USA) for 40 cycles. Each cycle consisted of denaturation for $30 \mathrm{~s}$ at $94^{\circ} \mathrm{C}$, annealing for $30 \mathrm{~s}$ at $60^{\circ} \mathrm{C}$, and extension for $30 \mathrm{~s}$ at $72^{\circ} \mathrm{C}$. A final extension step at $72^{\circ} \mathrm{C}$ for 5 min terminated the amplification. For each amplification, two types of controls were performed: (i) RT-PCR mixture with no reverse transcriptase to control for genomic DNA contamination and (ii) PCR mixture with no cDNA template, to check for possible external contamination. A $5 \mu \mathrm{L}$ sample of the PCR reaction was electrophoresed on an ethidium bromide-containing $2 \%$ agarose gel by the use of the Bio-Rad Subcell GT system. 
Quantitative Real-Time PCR (qPCR) was performed using SYBR Green on iQ5 Multicolor Real-Time PCR Detection System (Bio-Rad Laboratories, Inc., USA). The final reaction mixture contained $1 \mu \mathrm{L}$ of $\mathrm{cDNA}, 300 \mathrm{nM}$ of each primer, $7.5 \mu \mathrm{L}$ of iQ SYBR Green Supermix (Bio-Rad Laboratories, Inc., USA), and RNAse-free water to complete the reaction mixture volume to $15 \mu \mathrm{L}$. All reactions were run as triplicates. The QPCR was performed with a hotstart denaturation step at $95^{\circ} \mathrm{C}$ for $3 \mathrm{~min}$ and then was carried out for 40 cycles at $95^{\circ} \mathrm{C}$ for $10 \mathrm{~s}$ and at $60^{\circ} \mathrm{C}$ for $20 \mathrm{~s}$. The fluorescence was read during the reaction by the Opticon Monitor 3 software (Bio-Rad Laboratories, Inc., USA), allowing a continuous monitoring of the amount of PCR products. Primers have been initially used to generate a standard curve over a large dynamic range of starting cDNA quantity which allows to calculate the amplification efficiency (a critical value for the correct quantification of expression data) for each of the primer pairs. The melt curve analysis was performed at the end of each experiment to verify that a single product for primer pair was amplified (data not shown). As to control experiments, gel electrophoresis was also performed to verify the sizes of the amplified QPCR products. Ribosomal protein L13a (RPL13a), L11a (RPL11a), and GAPDH were used in our experiments as internal standards. As previously described, samples were compared using the relative cycle threshold (CT) method [38]. The fold increase or decrease was determined relative to a control after normalising to RPL13a (internal standard). The formula $2^{-\Delta \Delta C T}$ was used, where $\Delta \mathrm{CT}$ is (gene of interest CT) $-(\mathrm{RPL13A} \mathrm{CT})$, and $\Delta \Delta \mathrm{CT}$ is $(\Delta \mathrm{CT}$ experimental $)-(\Delta \mathrm{CT}$ control).

All the primers for qPCR analyses were GenBank obtained from Invitrogen (Invitrogen, Carlsbad, CA), and the sequences are listed Table 1.

2.7. Western Blot. After the experimental treatments, cells were washed with ice-cold phosphate-buffered saline solution (PBS), detached by scraping and transferred to eppendorf tubes. After $10 \mathrm{~min}$ centrifugation at $800 \times \mathrm{g}$ at $4^{\circ} \mathrm{C}$, the pellet was resuspended in ice-cold $10 \mathrm{mM} \mathrm{Na-phosphate} \mathrm{buffer,}$ pH 7.4, containing $1 \%$ Nonidet-P40, 0.5\% Na deoxycholate, $0.1 \%$ SDS, $1 \mu \mathrm{g} / \mathrm{mL}$ of pepstatin A, E-64, bestatin, leupeptin and aprotinin, and $25 \mu \mathrm{g} / \mathrm{mL}$ of PMSF. After $30 \mathrm{~min}$ on ice samples were centrifuged at $9,000 \times \mathrm{g}$ at $4^{\circ} \mathrm{C}$ for $20 \mathrm{~min}$. The supernatant was diluted 1.5 times with Laemmli buffer, boiled for $5 \mathrm{~min}$, and kept at $-20^{\circ} \mathrm{C}$ until use. Sample proteins were assessed according to Lowry et al. [39] using bovine serum albumin as standard. Western blotting procedures were carried out as we previously reported [29]; briefly, electrophoresis was carried out with a Mini Protean III apparatus $\left(28 \mathrm{~mA}, 2\right.$ hours at $\left.4^{\circ} \mathrm{C}\right)$, and the resolved proteins were transferred onto a nitrocellulose membrane $(300 \mathrm{~mA}, 1 \mathrm{~h}$ at $4^{\circ} \mathrm{C}$ ). Connexin, integrin, and estrogen receptor proteins were assessed by using $\mathrm{Cx} 40, \mathrm{Cx} 43, \mathrm{Cx} 45$, Int $\alpha 1$, Int $\alpha 5$, Int $\beta 1$, and ER- $\beta$ rabbit polyclonal antibodies (Santa Cruz Biotechnology Inc., CA, USA) against $\mathrm{Cx}$, integrin and estrogen receptor $\beta$ proteins were assessed by using rabbit polyclonal antibodies (Santa Cruz Biotechnology Inc. CA, USA) against proteins of human origin as primary antibodies $(1: 200)$. All antibodies were incubated overnight and, after washings, with goat anti-rabbit IgG colorimetric kit (Invitrogen, Carlsbad, CA) for $1 \mathrm{~h}$. Immunoblots were developed by enhanced colorimetric reagent kit (Invitrogen, Carlsbad, CA), and a densitometric analysis of the band intensities was performed by the Gel Doc 2000 video image system (BioRad Laboratories, Hercules, USA). Actin polyclonal antibody (Santa Cruz Biotechnology Inc., CA, USA) was used as an endogenous control for normalization. Values within each experiment were normalized to the control sample.

2.8. Indirect Immunofluorescence Staining of ER $\beta$. HTR$8 / \mathrm{SVneo}$ cells on coverslips were stained using rabbit polyclonal antibodies (Santa Cruz Biotechnology) raised against the human ER $\beta$ protein (H-150, working dilutions 1:200 in PBS containing $0.05 \%$ BSA and $0.1 \%$ sodium azide). Cells were incubated with the primary antibodies for $1 \mathrm{~h}$ at room temperature (RT) and with secondary FITC-labelled goat anti-rabbit IgG serum (Santa Cruz Biotechnology) diluted $1: 100$ in PBS, for $1 \mathrm{~h}$ at RT in the dark. Slides were mounted in Vectashield (Vector Laboratories, Burlingame, CA, USA) antifading and examined using an Epifluorescence microscope (Nikon Eclipse E800; Nikon Corporation, Surrey, UK) equipped with a plan apochromat $100 \times 0.5-1.3$ oil immersion objective and a mercury lamp source. Amplifier and detector optimising parameters were maintained constant for all the experiments.

2.9. Ultrastructural Study. Cells were scraped and collected in $0.1 \mathrm{M}$ cacodylate buffer ( $\mathrm{pH} 7.4$ ) and then spun in $1.5 \mathrm{~mL}$ tubes at $2,000 \times \mathrm{g}$ for $5 \mathrm{~min}$. Pellets were fixed with $2.5 \%$ glutaraldehyde in $0.1 \mathrm{M}$ sodium cacodylate buffer for $4 \mathrm{~h}$ at $4^{\circ} \mathrm{C}$. They were then washed with $0.1 \mathrm{M}$ cacodylate buffer $(\mathrm{pH}$ 7.4) three times and postfixed in $1 \%$ osmium tetroxide and $0.1 \mathrm{M}$ cacodylate buffer at $\mathrm{pH} 7.4$ for $1 \mathrm{~h}$ at room temperature. The specimens were dehydrated in graded concentrations of ethanol and embedded in epoxide resin (Agar Scientific, 66A Cambridge Road, Stansted Essex, CM24 8DA, UK).

Cells were then transferred to latex modules filled with resin and subsequently thermally cured at $60^{\circ} \mathrm{C}$ for $48 \mathrm{~h}$.

Semithin sections $(0.5-1 \mu \mathrm{m}$ thickness) were cut using an ultramicrotome (Reichard Ultracut S, Austria) stained with toluidine blue, and blocks were selected for thinning. Ultrathin sections of about 40-60 nm were cut and mounted onto formvar-coated copper grids. These were then doublestained with $1 \%$ uranyl acetate and $0.1 \%$ lead citrate for $30 \mathrm{~min}$ each and examined under a transmission electron microscope, Hitachi H-800 (Tokyo, Japan), at an accelerating voltage of $100 \mathrm{KV}$.

2.10. Statistical Analysis. All data were subjected to statistical analysis using PRISM software (version 2.1, Graph Pad Inc.). Data were examined by Bonferroni's posttest (2-way ANOVA). Specifically, tests were performed to ensure that the sham-exposed samples were not significantly different from one another. When these conditions were met, a second 1way ANOVA was performed on the data from the sham and HF-EMF exposed groups. In all cases statistically significant difference was accepted when $P<0.05$. 


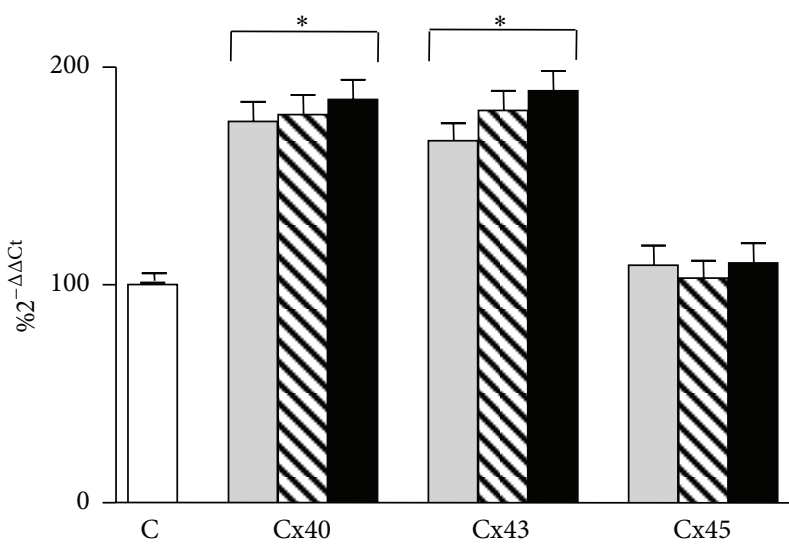

(a)

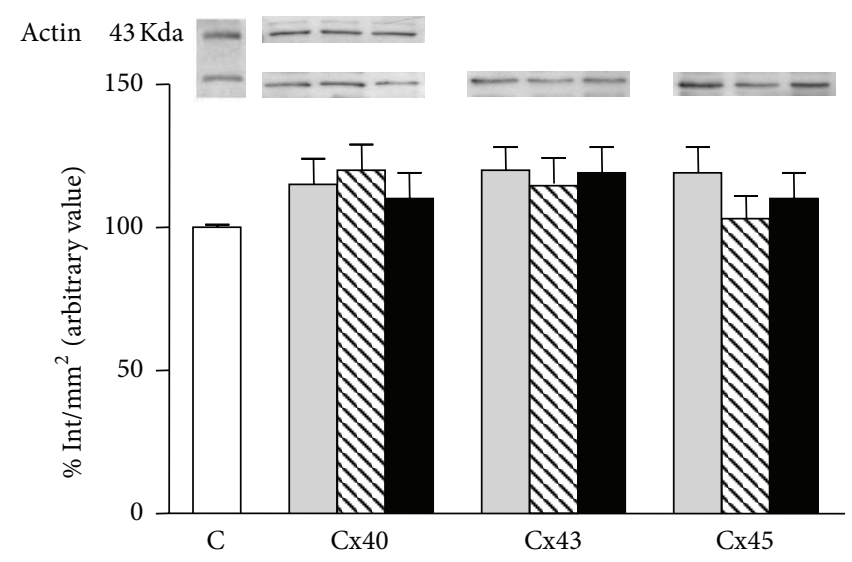

(b)

FIGURE 1: (a) Effect of HF-EMF (grey bar), $10^{-6} \mathrm{M} 17-\beta$-estradiol (hatched bar), and their combination (black bar) on the expression of Cx40, $\mathrm{Cx} 43$, and Cx45 mRNA in HTR-8/SVneo cells. Results are expressed in $\% 2^{-\Delta \Delta C T}$ with respect to the control value (white bar). (b) Western blot detection of CXs protein expression in HTR-8/SVneo cells HF-EMF exposed. Representative immunoblots of Cx40, Cx43, and Cx45 are shown. Results are the means \pm SEM of three independent experiments, each analysed in triplicate. Data are means \pm SEM of at least three independent experiments. ${ }^{*} P<0.001$ versus sham-exposed cells (one-way ANOVA followed by Bonferroni’s posttest).

\section{Results}

The aim of this work was to investigate the effects of electromagnetic fields on cell-cell and cell-matrix interactions in the first trimester of pregnancy and the control of these effects by the $17-\beta$-estradiol. To answer this question, we analyzed the effect of HF-EMF, 17- $\beta$-estradiol, and their combination on the expression of $\mathrm{Cx}$ and integrins in HTR-8/SVneo cells.

3.1. Viability of HTR-8/SVneo Cells. As revealed by MTT test, there was no significant difference in cells viability between the negative control (incubator) and the sham-exposed cells. Viability of exposed samples (1h to GSM-217 Hz signal) was always greater than $98 \%$ with respect to sham-exposed samples data not shown.

\subsection{Effect of HF-EMF, 17- $\beta$-Estradiol, and Their Combination} on Cx Expression in HTR-8/SVneo Cells. As already reported by Cervellati et al. [33], $1 \mathrm{~h}$ exposure to GSM-217 Hz signals significantly increased Cx40 (175\%; $P<0.001)$ and $\mathrm{Cx} 43$ (166\%; $P<0.001)$ mRNA expression as compared to shamexposed cells, whereas it did not change expression levels for Cx45 gene product (Figure 1(a)).

Treatment with $10^{-6} \mathrm{M} 17-\beta$-estradiol for $24 \mathrm{~h}$ significantly increased mRNA expression of Cx40 (178\%; $P<0.001)$ and $\mathrm{Cx} 43$ (180\%; $P<0.001)$ with respect to sham-exposed cells, whereas Cx45 mRNA remained unmodified (Figure 1).

When cells pretreated with $10^{-6} \mathrm{M} 17-\beta$-estradiol for $24 \mathrm{~h}$ were exposed to $1 \mathrm{~h}$ HF-EMF, we observed an increase for Cx40 and $\mathrm{Cx} 43$ (185\%; $P<0.001,189 \% ; P<0.001$, resp.) mRNA expression similar to that found in the presence of HF-EMF or steroid hormone alone. As for Cx45 mRNA, also the combination of the two treatments did not induce any significant change (Figure 1(a)).

All treatments produced no effect on protein expression, at the same experimental conditions (Figure 1(b)).
3.3. Effect of HF-EMF, 17- $\beta$-Estradiol, and Their Combination on Integrin Expression in HTR-8/SVneo Cells. HF-EMF exposure for $1 \mathrm{~h}$ significantly decreased $\alpha 1$ subunit (55\%; $P<$ $0.001)$ and $\beta 1$ subunit $(25 \% ; P<0.001)$ mRNA levels, but it significantly enhanced $\alpha 5$ subunit $(+50 \% ; P<0.001)$ mRNA expression with respect to sham-exposed cells (Figure 2(a)).

All the integrin subunit mRNA expressions were significantly increased $(230 \%, P<0.001$ for $\alpha 1 ; 167 \%, P<0.001$ for $\alpha 5 ; 127 \%, P<0.001$ for $\beta 1$ ) by 24 h treatment with $10^{-6} \mathrm{M}$ 17 - $\beta$-estradiol (Figure 2(a)).

An effect similar to that obtained in the presence of $17-\beta$ estradiol treatment was found when the cells were pretreated with the hormone for $24 \mathrm{~h}$ and then exposed to $1 \mathrm{~h}$ HF-EMF. In fact mRNA expression for all integrins tested significantly augmented with respect to sham-exposed cells $(203 \%, P<$ 0.001 for $\alpha 1$; $160 \%, P<0.001$ for $\alpha 5 ; 118 \%, P<0.001$ for $\beta 1$ ) (Figure 2(a)).

All treatments produced no effect on protein expression, at the same experimental conditions (Figure 2(b)).

3.4. Expression of ER Subtypes in Human Chorionic Villi and HTR-8/SVneo Cells. Both ER- $\alpha$ and ER- $\beta$ subtypes were expressed in human chorionic villi, as previously reported [26]. In HTR-8/SVneo cells, instead, only ER- $\beta$ isoform was present whereas ER- $\alpha$ isoform was not detectable (Figure 3).

\subsection{Effect of HF-EMF, 17- $\beta$-Estradiol, and Their Combination} on ER- $\beta$ Expression in HTR-8/SVneo Cells. The $1 \mathrm{~h}$ exposure to GSM-217 Hz signal significantly reduced mRNA expression of ER- $\beta$ (35\%, $P<0.001$ ) whereas $10^{-6} \mathrm{M} 17-\beta$ estradiol for $24 \mathrm{~h}$ significantly increased the receptor mRNA expression $(210 \%, P<0.001)$, with respect to sham-exposed cells. A stimulatory effect $(180 \%, P<0.001)$ on ER- $\beta$ mRNA level was also found when cells pretreated with the steroid hormone for $24 \mathrm{~h}$ were then exposed for $1 \mathrm{~h}$ to HF-EMF (Figure 4(a)). 


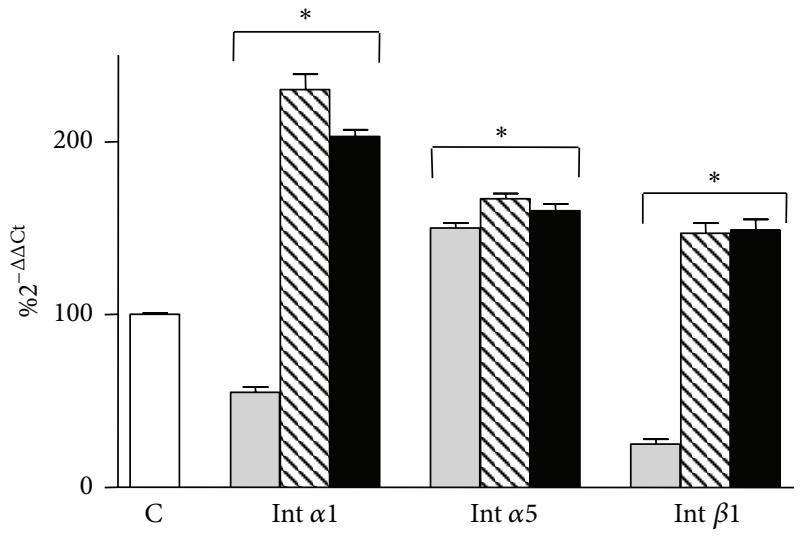

(a)

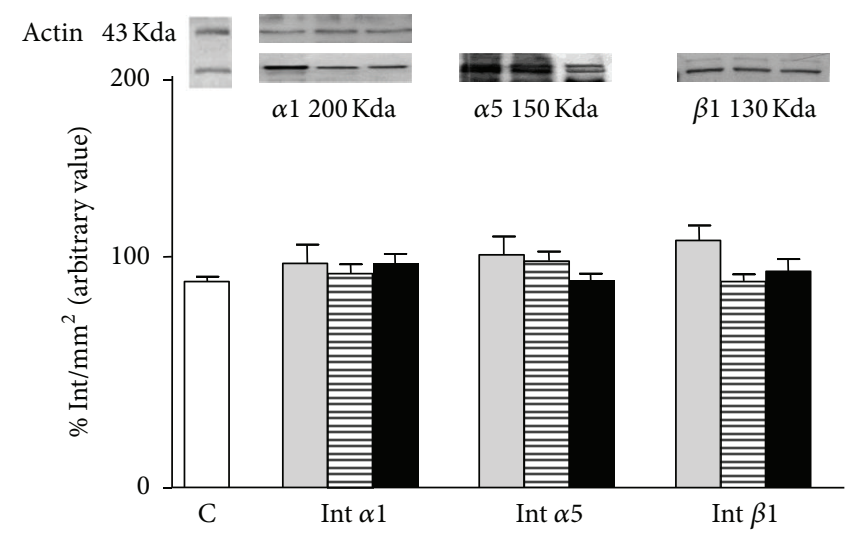

(b)

Figure 2: (a) Effect of HF-EMF (grey bar), $10^{-6} \mathrm{M}$ 17- $\beta$-estradiol (hatched bar), and their combination (black bar) on the expression of Int $\alpha 1$, Int $\alpha 5$, and Int $\beta 1$ mRNA in HTR-8/SVneo cells. Results are expressed in $\% 2^{-\Delta \Delta C T}$ with respect to the control value (white bar). (b) Western blot detection of Integrins Int $\alpha 1$, Int $\alpha 5$, and Int $\beta 1$ subunit proteins expression in HTR-8/SVneo cells HF-EMF exposed. Results are the means \pm SEM of three independent experiments, each analysed in triplicate. Data are means \pm SEM of at least three independent experiments. ${ }^{*} \mathrm{P}<0.001$ versus sham-exposed cells (one-way ANOVA followed by Bonferroni's posttest).

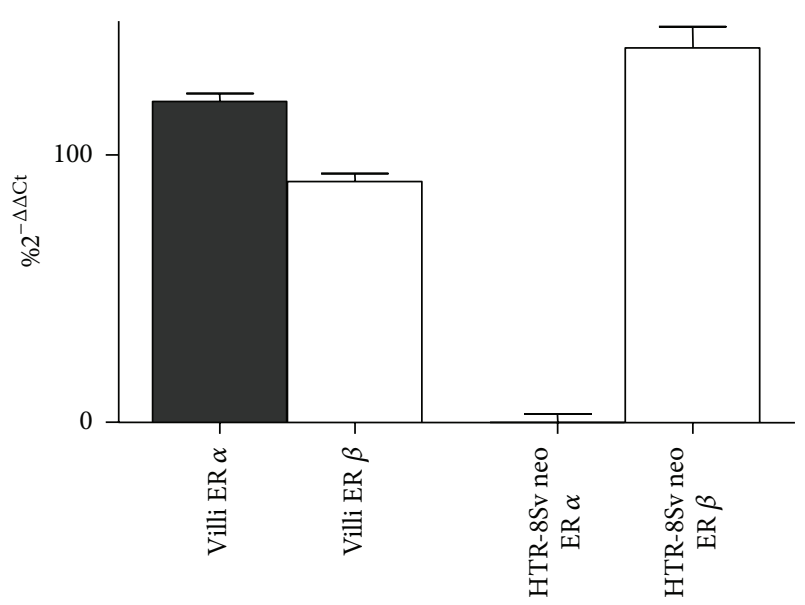

FIGURE 3: Expression of ER in first trimester human villi and in HTR-8/SVneo cells. Results are expressed in $\% 2^{-\Delta \Delta C T}$ with respect to the housekeeping gene. Data are means \pm SEM of at least three independent experiments. ${ }^{*} P<0.001$ versus sham-exposed cells (one-way ANOVA followed by Bonferroni's posttest).

All treatments produced no effect on protein expression, at the same experimental conditions (Figure 4(b)).

\subsection{Effect of HF-EMF, 17- $\beta$-Estradiol, and Their Combina-} tion on ER- $\beta$ Immunolocalization in HTR-8/SVneo Cells. In sham-exposed cells we found punctuate fluorescence for ER$\beta$ predominantly in the cytoplasm (Figure 5(a)). The $1 \mathrm{~h} \mathrm{HF}-$ EMF irradiated cells showed a fluorescence distribution for ER- $\beta$ comparable to that observed in sham-exposed cells (Figure 5(b)). When the cells were treated with $10^{-6} \mathrm{M} 17-$ $\beta$-estradiol for $24 \mathrm{~h}$, a nuclear translocation of ER- $\beta$ fluorescence was observed (Figure 5(c)). A similar effect was induced by pretreatment with $10^{-6} \mathrm{M} 17-\beta$-estradiol for $24 \mathrm{~h}$ followed by $1 \mathrm{~h}$ exposure to HF-EMF (Figure 5(d)).
3.7. Effect of HF-EMF, 17- $\beta$-Estradiol, and Their Combination on Ultrastructural Features in HTR-8/SVneo Cells. As already reported [33], electron microscopy examinations of selected areas of sham-exposed HTR-8/SVneo cells showed neighbouring cells in apposition with each other (Figure 6(a)). A decrease in cellular adhesion was found when cells were exposed to $1 \mathrm{~h}$ HF-EMF (Figure 6(b)). On the contrary, following $10^{-6} \mathrm{M} 17-\beta$-estradiol treatment for $24 \mathrm{~h}, \mathrm{HTR}-8 / \mathrm{SVneo}$ cells formed tightly adherent cellular islets (Figure 6(c)). Cells exposed for $1 \mathrm{~h}$ to HF-EMF and pretreated with the steroid hormone for $24 \mathrm{~h}$ did not show ultrastructural morphological changes in comparison with cells treated with $10^{-6}$ M 17- $\beta$-estradiol alone (Figure 6(d)).

\section{Discussion}

Human placental development critically relies upon the differentiation of cytotrophoblast stem cells towards the villous and the invasive extravillous pathways. During this process a pivotal role is played by interactions between trophoblast cells and extracellular matrix, mediated by various kinds of adhesion molecules such as Cxs and Ints [16]. For instance, trophoblast cells lose $\alpha 6 \beta 4$ and gain $\alpha 5 \beta 1$ and $\alpha 1 \beta 1$ Ints [40], and they decrease Cx40-containing gap junctions, while increasing $\alpha 1$ integrin expression $[13,41]$. Expressions of both Cxs and Ints are affected by hormones [15] as well as by environmental stresses $[42,43]$.

As for hormonal regulation of $\mathrm{Cx}$ expression, estrogens were reported to increase $\mathrm{Cx} 43$ and cell to cell communication in human myometrial cultured cells [44]. Moreover, they induce $\mathrm{Cx} 26$ and $\mathrm{Cx} 43$ in rat endometrium during preimplantation, implantation, and decidualization [45]. In human trophoblast $17-\beta$-estradiol regulates the expression of $\mathrm{Cx} 43$ that is involved in differentiation from cyto- to syncytiotrophoblast, as well as EVT from the proliferative to the invasive phenotype [12]. In the present work, using a 


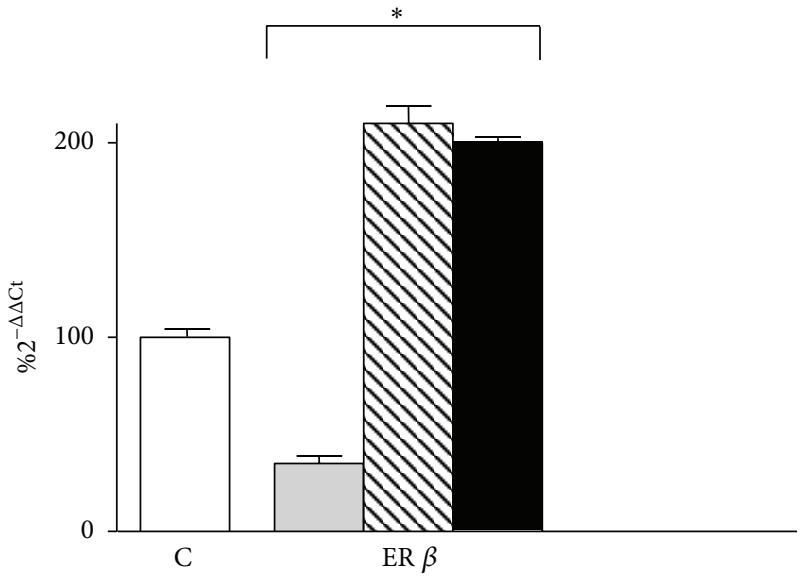

(a)

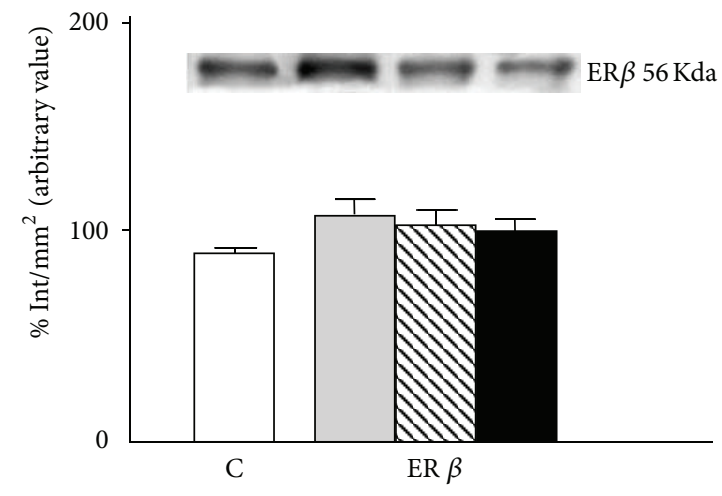

(b)

Figure 4: (a) Effect of HF-EMF (grey bar), $10^{-6} \mathrm{M}$ 17- $\beta$-estradiol (hatched bar), and their combination (black bar) on the expression of ER $\beta$ mRNA in HTR-8/SVneo cells. Results are expressed in $\% 2^{-\Delta \Delta C T}$ with respect to the control value (white bar). (b) Western blot detection of ER $\beta$ protein expression in HF-EMF-exposed HTR-8/SVneo cells. Results are the means \pm SEM of three independent experiments, each analysed in triplicate. Data are means \pm SEM of at least three independent experiments. ${ }^{*} P<0.001$ versus sham-exposed cells (one-way ANOVA followed by Bonferroni's posttest).

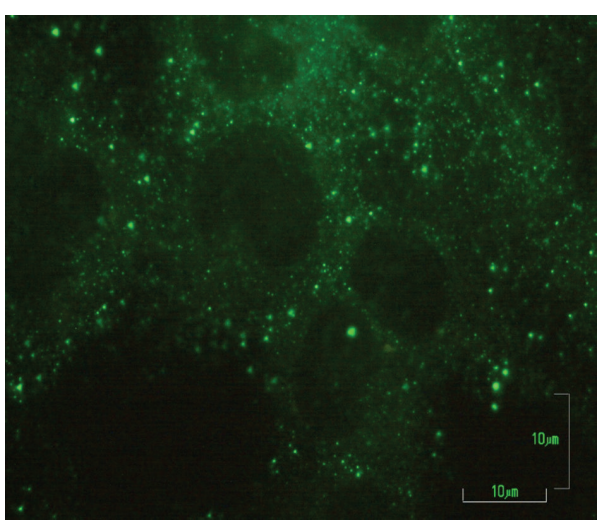

(a)

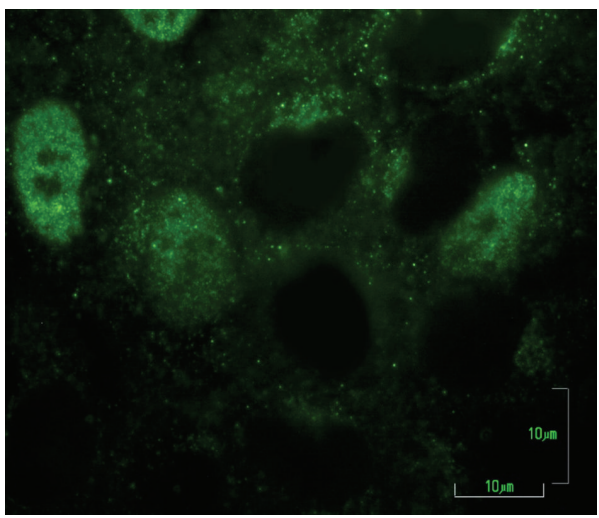

(c)

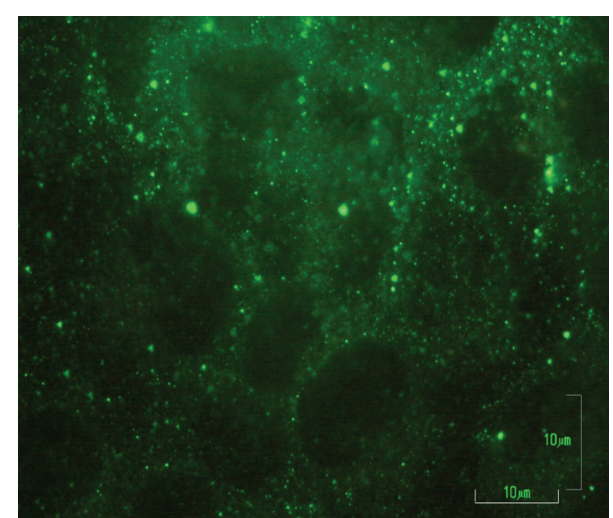

(b)

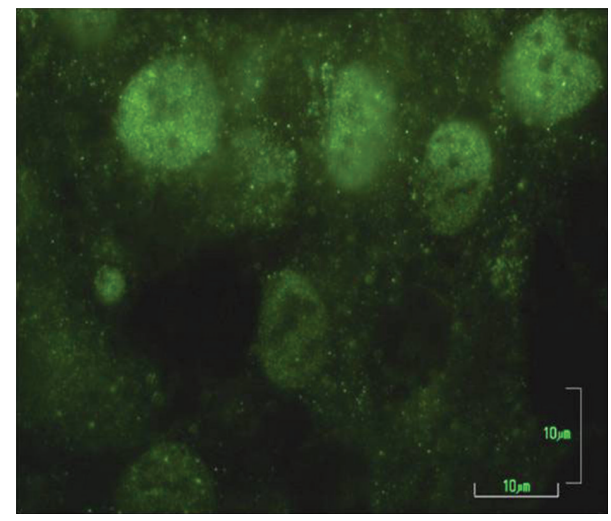

(d)

FIGURE 5: Indirect immunofluorescence staining of ER $\beta$ in HTR-8/SVneo cells. (a) Sham-exposed cells; (b) HF-EMF-exposed cells; (c) shamexposed $+10^{-6}$ M 17- $\beta$-estradiol; (d) HF-EMF $+10^{-6}$ M 17- $\beta$-estradiol exposed cells. Scale bars $=10 \mu \mathrm{m}$. 


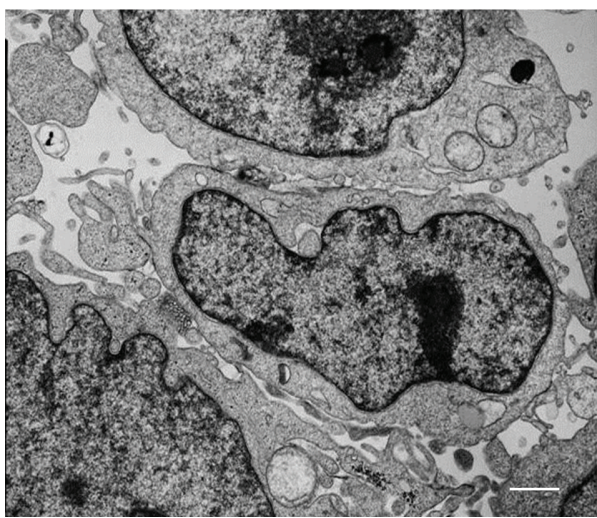

(a)

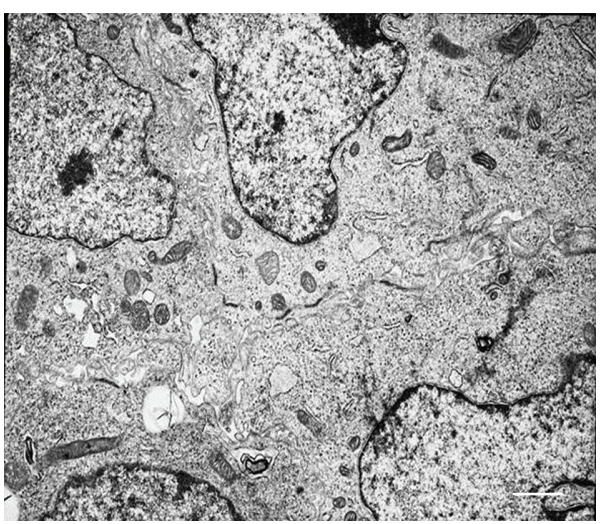

(c)

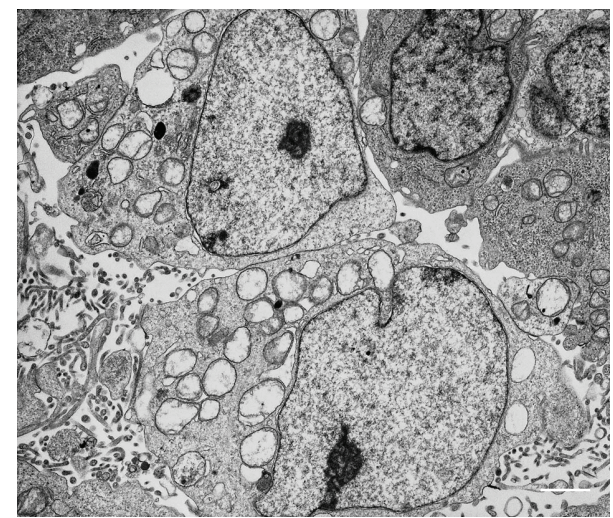

(b)

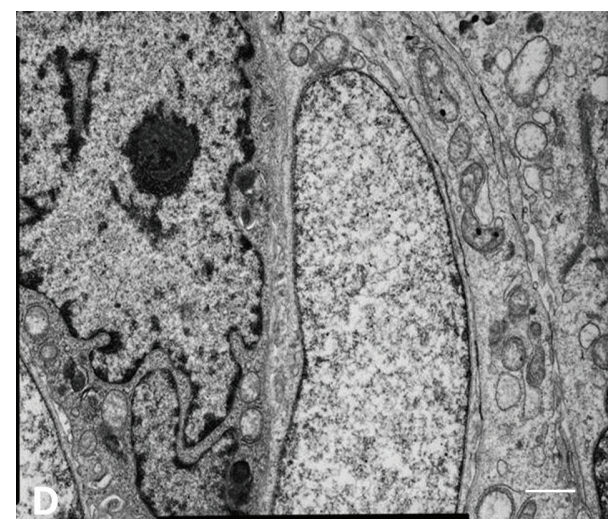

(d)

FIGURE 6: Electron microscopy of HTR-8/SVneo confluent culture cells under different experimental conditions. (a) Sham exposed-cells; (b) HF-EMF exposed cells; (c) $10^{-6}$ M 17- $\beta$-estradiol; (d) $10^{-6}$ M 17- $\beta$-estradiol + HF-EMF exposed cells. Bars $=2 \mu \mathrm{m}$.

well-characterized model of human EVT, the HTR-8/SVneo cell line, we investigated the effect of HF-EMF, estradiol, and their combination on $\mathrm{Cx}$, Int, and ER expression as well as on cell ultrastructure. In our cell line either HF-EMF or 17- $\beta$-estradiol, both alone or in combination, increased $\mathrm{Cx} 40$ and $\mathrm{Cx} 43$ mRNA expression leaving unaltered $\mathrm{Cx} 45$ transcript. As already showed in our foregoing paper [33] with regard to HF-EMF effect on $\mathrm{Cx}$ protein expression, in the present study $17-\beta$-estradiol and its combination with HF-EMF did not induce any change in $\mathrm{Cx}$ protein levels. Accordingly, a discrepancy between mRNA transcript and protein expression had already been reported both in EVT cells and other cell types regarding different genes and proteins $[46,47]$.

As for Ints, the expressions of $\alpha 1, \alpha 5$, and $\beta 1$ were already shown in HTR-8/SVneo cells [48, 49].

Very little is known, however, about the effect of HFEMF on Int expression. Pulsed electromagnetic fields had no effect in osteosarcoma cell line [50], but extremely low frequency magnetic fields induced a segregation of $\alpha 4$ integrin in human keratinocytes, suggesting an interference with cellular adhesion [51]. In human decidua during early pregnancy the regulation of extracellular matrix remodeling as well as integrin switching is at least partially modulated by reproductive hormones $[15,52]$.

In our study we demonstrate, for the first time, that both HF-EM and 17- $\beta$-estradiol were able to modulate the expression of these adhesion molecules. In fact $1 \mathrm{~h}$ exposure to HF-EMF decreased $\alpha 1$ and $\beta 1$ Int subunit mRNA levels, while increasing $\alpha 5$ transcript. On the contrary 17$\beta$-estradiol induced an enhancement of all the Int subunit mRNA expressions. These data suggest that the hormone may exert an action promoting trophoblast differentiation along the invasive pathway, contrary to HF-EMF. Moreover, $17-\beta$ estradiol effect seemed to prevail over the electromagnetic field one, since the treatment with both agents provoked results comparable to those obtained in the presence of the estrogen alone. However, once again, no effect on protein expression was detected in any experimental condition. Accordingly, 24 h estradiol treatment did not affect Int $\alpha 5$ and Int $\beta 4$ proteins in human decidua [52]. Nevertheless, integrin protein expression enhancement by estradiol was reported in other experimental conditions $[15,53]$.

Conflicting results have been reported on estrogen receptor in human placenta $[15,26,54]$, although the $\alpha$ isoform has been found in first trimester human chorionic villi [55].

However, in our study, we detected the presence of the ER- $\beta$ isoform, while ER- $\alpha$ isoform was undetectable either in basal or in stimulated conditions, thus suggesting a mature state of differentiation for HTR-8/SVneo cells [26]. Therefore, $17-\beta$-estradiol stimulatory action on both $\mathrm{Cx}$ and Int mRNA levels should be mediated by the ER- $\beta$ isoform receptor. In our data ER- $\beta$ receptor subtype mRNA was reduced by HF-EMF exposure but enhanced by $17-\beta$-estradiol treatment. 
Also in this case the HF-EMF reductive effect was blinded by $24 \mathrm{~h}$ hormone pretreatment. These data suggest a putative autocrine action of estrogen on its own receptor in HTR$8 /$ SVneo cells, as already reported in placental cells with regard to ER- $\alpha$ [15]. Although no significant modifications at the protein level were found, localization of ER- $\beta$ isoform was notably influenced by hormonal treatment. In fact a nuclear translocation of ER- $\beta$ fluorescence became evident after estrogen exposure, also in the presence of HF-EMF which, per se, did not alter the cytoplasmic localization.

Ultrastructural observation seemed to reflect the results found at the Int mRNA level. In fact, hormone treatment ameliorated adhesion between neighboring cells, favoring the formation of compact cellular islet. HF-EMF exposure, instead, seemed to increase the distance between adjacent cells. Moreover, estradiol was able to preserve the ultrastructural features of HTR-8/SVneo cells also in the presence of the electromagnetic field.

Thus it can be hypothesized that estradiol may facilitate decidual stroma invasion reinforcing adhesion between cells and extracellular matrix, probably through a modulation of Int subunits, even if we were not able to detect any effect on Int protein expression. This may be due to translational and posttranslational regulation of these adhesion molecules [56]. It is well established that antibodies that interfere with integrin ligand occupancy not only inhibit cell attachment to the ECM but also inhibit cell movement [57].

At this regard it is important to consider that a dysregulation of the previously mentioned molecules is associated to pregnancy disorders such as preeclampsia, IUGR, and preterm labour [16]. As for the mechanism of 17- $\beta$-estradiol action, the protective efficacy of the hormone against oxidative stress can be hypothesized. Indeed, in ARTE-19 cells it has been shown to exert an ER- $\beta$-mediated cytoprotection through the preservation of mitochondrial function, reduction of reactive oxygen species production, and induction of cellular antioxidant genes [58].

\section{Conclusions}

Growing attention is devoted today, even from international political institutions, to the influence of HF-EMF on human health, in particular following the recent report that exposure to cell phone radiofrequency signal increases brain glucose metabolism [59]. In the context of human pregnancy protection, it appears mandatory not only to investigate the effects of HF-EMF on implantation, morphogenesis, and fetal development, but also to ascertain the possible existence of protective physiological control mechanisms. At this regard, our study shows, for the first time, that $17-\beta$-estradiol is able to counteract the effects of HF-EMF on trophoblastic $\mathrm{Cx}$, integrins, and ER.

\section{Conflict of Interests}

On the behalf of all the authors, we declare that there is no conflict of interests.

\section{References}

[1] M. Kundi, K. H. Mild, L. Hardell, and M. O. Mattsson, "Mobile telephones and cancer-a review of epidemiological evidence," Journal of Toxicology and Environmental Health B, vol. 7, no. 5, pp. 351-384, 2004.

[2] P. A. Valberg, E. van Deventer, and M. H. Repacholi, "Workgroup report: Base stations and wireless networksradiofrequency (RF) exposures and health consequences," Environmental Health Perspectives, vol. 115, no. 3, pp. 416-424, 2007.

[3] N. D. Volkow, D. Tomasi, G. J. Wang et al., "Effects of cell phone radiofrequency signal exposure on brain glucose metabolism," Journal of the American Medical Association, vol. 305, no. 8, pp. 808-813, 2011.

[4] H. Lai and L. Hardell, "Cell phone radiofrequency radiation exposure and brain glucose metabolism," Journal of the American Medical Association, vol. 305, no. 8, pp. 828-829, 2011.

[5] R. P. Jensh, "Behavioral teratologic studies using microwave radiation: is there an increased risk from exposure to cellular phones and microwave ovens?" Reproductive Toxicology, vol. 11, no. 4, pp. 601-611, 1997.

[6] M. E. O'Connor, "Intrauterine effects in animals exposed to radiofrequency and microwave fields," Teratology, vol. 59, pp. 287-291, 1999.

[7] T. I. Subbotina, A. A. Khadartsev, M. A. Yashin, and A. A. Yashin, "Effect of high-frequency low-intensity irradiation on reproductive function in $\mathrm{C} 57 \mathrm{Bl} / 6$ and randombred mice," Bulletin of Experimental Biology and Medicine, vol. 138, no. 6, pp. 554-555, 2004.

[8] A. Agarwal, F. Deepinder, R. K. Sharma, G. Ranga, and J. Li, "Effect of cell phone usage on semen analysis in men attending infertility clinic: an observational study," Fertility and Sterility, vol. 89, no. 1, pp. 124-128, 2008.

[9] M. Redmayne, E. Smith, and M. J. Abramson, "Adolescent inschool cellphone habits: a census of rules, survey of their effectiveness, and fertility implications," Reproductive Toxicolog, vol. 32, no. 3, pp. 354-359, 2011.

[10] G. N. De Iuliis, R. J. Newey, B. V. King, and R. J. Aitken, "Mobile phone radiation induces reactive oxygen species production and DNA damage in human spermatozoa In vitro," PLoS ONE, vol. 4, no. 7, Article ID e6446, 2009.

[11] L. Lunghi, M. E. Ferretti, S. Medici, C. Biondi, and F. Vesce, "Control of human trophoblast function," Reproductive Biology and Endocrinology, vol. 5, article 6, 2007.

[12] L. Cronier, J. L. Frendo, N. Defamie et al., "Requirement of gap junctional intercellular communication for human villous trophoblast differentiation," Biology of Reproduction, vol. 69, no. 5, pp. 1472-1480, 2003.

[13] T. Nishimura, C. Dunk, Y. Lu et al., "Gap junctions are required for trophoblast proliferation in early human placental development," Placenta, vol. 25, no. 7, pp. 595-607, 2004.

[14] A. Malassiné and L. Cronier, "Involvement of gap junctions in placental functions and development," Biochimica et Biophysica Acta, vol. 1719, pp. 117-124, 2005.

[15] C. Das and S. Basak, "Expression and regulation of integrin receptors in human trophoblast cells: role of estradiol and cytokines," Indian Journal of Experimental Biology, vol. 41, no. 7, pp. 748-755, 2003.

[16] L. K. Harris, C. J. P. Jones, and J. D. Aplin, "Adhesion molecules in human trophoblast-a review. II. Extravillous trophoblast," Placenta, vol. 30, no. 4, pp. 299-304, 2009. 
[17] H. Dbouk, R. M. Mroue, M. El-Sabban, and R. S. Talhouk, "Connexins: a myriad of functions extending beyond assembly of gap junction channels," Cell Signaling Technology, vol. 7, pp. $1-17,2009$.

[18] S. Schmidt and P. Friedl, "Interstitial cell migration: integrindependent and alternative adhesion mechanisms," Cell and Tissue Research, vol. 339, no. 1, pp. 83-92, 2010.

[19] J. D. Aplin, C. J. P. Jones, and L. K. Harris, "Adhesion molecules in human trophoblast-a review. I. Villous trophoblast," Placenta, vol. 30, no. 4, pp. 293-298, 2009.

[20] C. Damsky, "Cell-cell and cell-extracellular matrix adhesion receptors," Annals of the New York Academy of Sciences, vol. 961, pp. 154-155, 2002.

[21] S. H. Jeong, S. S. M. Habeebu, and C. D. Klaassen, "Cadmium decreases gap junctional intercellular communication in mouse liver," Toxicological Sciences, vol. 57, no. 1, pp. 156-166, 2000.

[22] E. I. Azzam, S. M. De Toledo, and J. B. Little, "Expression of Connexin 43 is highly sensitive to ionizing radiation and other environmental stresses," Cancer Research, vol. 63, no. 21, pp. 7128-7135, 2003.

[23] F. Lamari, F. Braut-Boucher, N. Pongnimitprasert et al., "Cell adhesion and integrin expression are modulated by oxidative stress in EA.hy 926 cells," Free Radical Research, vol. 41, no. 7, pp. 812-822, 2007.

[24] L. Cronier, E. Alsat, J. C. Harvè, J. Déléze, and A. Malassinè, "Dexamethasone stimulates gap junctional communication, peptide hormones production and differentiation in human term trophoblast," Placenta, vol. 19, supplement 1, pp. 35-49, 1998.

[25] L. Cronier, J. Guibourdenche, C. Niger, and A. Malassiné, "Oestradiol stimulates morphological and functional differentiation of human villous cytotrophoblast," Placenta, vol. 20, no. 8, pp. 669-676, 1999.

[26] A. Bukovsky, M. Cekanova, M. R. Caudle et al., "Expression and localization of estrogen receptor-alpha protein in normal and abnormal term placentae and stimulation of trophoblast differentiation by estradiol," Reproductive Biology and Endocrinology, vol. 1, article 13, 2003.

[27] A. Malassiné and L. Cronier, "Hormones and human trophoblast differentiation: a review," Endocrine, vol. 19, no. 1, pp. 3-11, 2002.

[28] S. Rama, P. Petrusz, and A. J. Rao, "Hormonal regulation of human trophoblast differentiation: a possible role for $17 \beta$ estradiol and GnRH," Molecular and Cellular Endocrinology, vol. 218, no. 1-2, pp. 79-94, 2004.

[29] R. Yashwanth, S. Rama, M. Anbalagan, and A. J. Rao, "Role of estrogen in regulation of cellular differentiation: a study using human placental and rat Leydig cells," Molecular and Cellular Endocrinology, vol. 246, no. 1-2, pp. 114-120, 2006.

[30] S. Kwee, P. Raskmark, and S. Velizarov, "Changes in cellular proteins due to environmental non-ionizing radiation. I. Heatshock proteins," Electro- and Magnetobiology, vol. 20, no. 2, pp. 141-152, 2001.

[31] P. Valbonesi, S. Franzellitti, A. Piano, A. Contin, C. Biondi, and E. Fabbri, "Evaluation of HSP70 expression and DNA damage in cells of a human trophoblast cell line exposed to $1.8 \mathrm{GHz}$ amplitude-modulated radiofrequency fields," Radiation Research, vol. 169, no. 3, pp. 270-279, 2008.

[32] J. A. Irving, J. J. Lysiak, C. H. Graham, S. Hearn, V. K. M. Han, and P. K. Lala, "Characteristics of trophoblast cells migrating from first trimester chorionic villus explants and propagated in culture," Placenta, vol. 16, no. 5, pp. 413-433, 1995.
[33] F. Cervellati, G. Franceschetti, L. Lunghi et al., "Effect of highfrequency electromagnetic fields on trophoblastic connexins," Reproductive Toxicology, vol. 28, no. 1, pp. 59-65, 2009.

[34] F. Pattyn, P. Robbrecht, A. De Paepe, F. Speleman, and J. Vandesompele, "RTPrimerDB: the real-time PCR primer and probe database, major update 2006," Nucleic Acids Research, vol. 34, pp. D684-D688, 2006.

[35] J. C. W. Comley, S. Townson, M. J. Rees, and A. Dobinson, "The further application of MTT-formazan colorimetry to studies on filarial worm viability," Tropical Medicine and Parasitology, vol. 40, no. 3, pp. 311-316, 1989.

[36] J. Czyz, K. Guan, Q. Zeng, and A. M. Wobus, "Loss of betal integrin function results in upregulation of connexin expression in embryonic stem cell-derived cardiomyocytes," International Journal of Developmental Biology, vol. 49, no. 1, pp. 33-41, 2005.

[37] P. Valbonesi, S. Franzellitti, A. Piano, A. Contin, C. Biondi, and E. Fabbri, "Evaluation of HSP70 expression and DNA damage in cells of a human trophoblast cell line exposed to $1.8 \mathrm{GHz}$ amplitude-modulated radiofrequency fields," Radiation Research, vol. 169, no. 3, pp. 270-279, 2008.

[38] K. J. Livak and T. D. Schmittgen, "Analysis of relative gene expression data using real-time quantitative PCR and the 2$\Delta \Delta$ CT method," Methods, vol. 25, no. 4, pp. 402-408, 2001.

[39] O. H. Lowry, N. J. Rosebrough, A. L. Farr, and R. J. Randall, "Protein measurement with the Folin phenol reagent," The Journal of Biological Chemistry, vol. 193, no. 1, pp. 265-275, 1951.

[40] C. H. Damsky, M. L. Fitzgerald, and S. J. Fisher, "Distribution patterns of extracellular matrix components and adhesion receptors are intricately modulated during first trimester cytotrophoblast differentiation along the invasive pathway, In vivo," Journal of Clinical Investigation, vol. 89, no. 1, pp. 210-222, 1992.

[41] J. K. Wright, C. E. Dunk, J. E. Perkins, E. Winterhager, J. C. P. Kingdom, and S. J. Lye, "EGF modulates trophoblast migration through regulation of connexin 40," Placenta, vol. 27, pp. 114121, 2006.

[42] C. Jean, P. Gravelle, J. J. Fournie, and G. Laurent, "Influence of stress on extracellular matrix and integrin biology," Oncogene, vol. 30, no. 24, pp. 2697-2706, 2011.

[43] N. Cordes and V. Meineke, "Integrin signalling and the cellular response to ionizing radiation," Journal of Molecular Histology, vol. 35, no. 3, pp. 327-337, 2004.

[44] W. L. Di, G. C. L. Lachelin, H. H. G. McGarrigle, N. S. B. Thomas, and D. L. Becker, "Oestriol and oestradiol increase cell to cell communication and connexin 43 protein expression in human myometrium," Molecular Human Reproduction, vol. 7, no. 7, pp. 671-679, 2001.

[45] R. Grümmer, S. W. Hewitt, O. Traub, K. S. Korach, and E. Winterhager, "Different regulatory pathways of endometrial connexin expression: preimplantation hormonal-mediated pathway versus embryo implantation-initiated pathway," Biology of Reproduction, vol. 71, no. 1, pp. 273-281, 2004.

[46] S. Franzellitti, P. Valbonesi, A. Contin, C. Biondi, and E. Fabbri, "HSP70 expression in human trophoblast cells exposed to different 1.8 GHz mobile phone signals," Radiation Research, vol. 170, no. 4, pp. 488-497, 2008.

[47] T. Nikolova, J. Czyz, A. Rolletschek et al., "Electromagnetic fields affect transcript levels of apoptosis-related genes in embryonic stem cell-derived neural progenitor cells," The FASEB Journal, vol. 19, no. 12, pp. 1686-1688, 2005.

[48] P. A. Elustondo, G. E. Hannigan, I. Caniggia, and D. J. MacPhee, "Integrin-linked kinase (ILK) is highly expressed in 
first trimester human chorionic villi and regulates migration of a human cytotrophoblast-derived cell line," Biology of Reproduction, vol. 74, no. 5, pp. 959-968, 2006.

[49] M. Jovanović and L. Vićovac, "Interleukin-6 stimulates cell migration, invasion and integrin expression in HTR-8/SVneo cell line," Placenta, vol. 30, no. 4, pp. 320-328, 2009.

[50] D. Zhang, X. Pan, S. Ohno, T. Osuga, S. Sawada, and K. Sato, "No effects of pulsed electromagnetic fields on expression of cell adhesion molecules (integrin, CD44) and matrix metalloproteinase-2/9 in osteosarcoma cell lines," Bioelectromagnetics, vol. 32, no. 6, pp. 463-473, 2011.

[51] V. Manni, A. Lisi, D. Pozzi et al., "Effects of extremely low frequency $(50 \mathrm{~Hz})$ magnetic field on morphological and biochemical properties of human keratinocytes," Bioelectromagnetics, vol. 23, no. 4, pp. 298-305, 2002.

[52] U. A. Kayisli, E. T. Korgun, G. Akkoyunlu, A. Arici, and R. Demir, "Expression of integrin $\alpha 5$ and integrin $\beta 4$ and their extracellular ligands fibronectin and laminin in human decidua during early pregnancy and its sex steroid-mediated regulation," Acta Histochemica, vol. 107, no. 3, pp. 173-185, 2005.

[53] C. Das, V. S. Kumar, S. Gupta, and S. Kumar, "Network of cytokines, integrins and hormones in human trophoblast cells," Journal of Reproductive Immunology, vol. 53, no. 1-2, pp. 257268, 2002.

[54] B. Schiessl, I. Mylonas, C. Kuhn et al., "Expression of estrogen receptor- $\alpha$, estrogen receptor- $\beta$ and placental endothelial and inducible NO synthase in intrauterine growth-restricted and normal placentals," Archives of Medical Research, vol. 37, no. 8, pp. 967-975, 2006.

[55] C. X. Meng, L. N. Cheng, P. G. L. Lalitkumar, L. Zhang, H. J. Zhang, and K. Gemzell-Danielsson, "Expressions of steroid receptors and Ki67 in first-trimester decidua and chorionic villi exposed to levonorgestrel used for emergency contraception," Fertility and Sterility, vol. 91, no. 4, pp. 1420-1423, 2009.

[56] K. Nelson, V. Helmstaedter, C. Moreau, and H. Lage, "Estradiol, tamoxifen and ICI 182,780 alter $\alpha 3$ and $\beta 1$ integrin expression and laminin-1 adhesion in oral squamous cell carcinoma cell cultures," Oral Oncology, vol. 44, no. 1, pp. 94-99, 2008.

[57] S. P. Holly, M. K. Larson, and L. V. Parise, "Multiple roles of integrins in cell motility," Experimental Cell Research, vol. 261, no. 1, pp. 69-74, 2000.

[58] A. Giddabasappa, M. Bauler, M. Yepuru, E. Chaum, J. T. Dalton, and J. Eswaraka, "17- $\beta$ estradiol protects ARPE-19 cells from oxidative stress through estrogen receptor- $\beta$," Investigative Ophthalmology \& Visual Science, vol. 51, pp. 5278-5287, 2010.

[59] N. D. Volkow, D. Tomasi, G. J. Wang et al., "Effects of cell phone radiofrequency signal exposure on brain glucose metabolism," Journal of the American Medical Association, vol. 305, no. 8, pp. 808-813, 2011. 


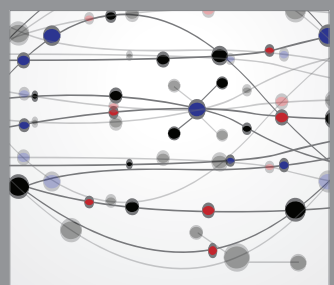

The Scientific World Journal
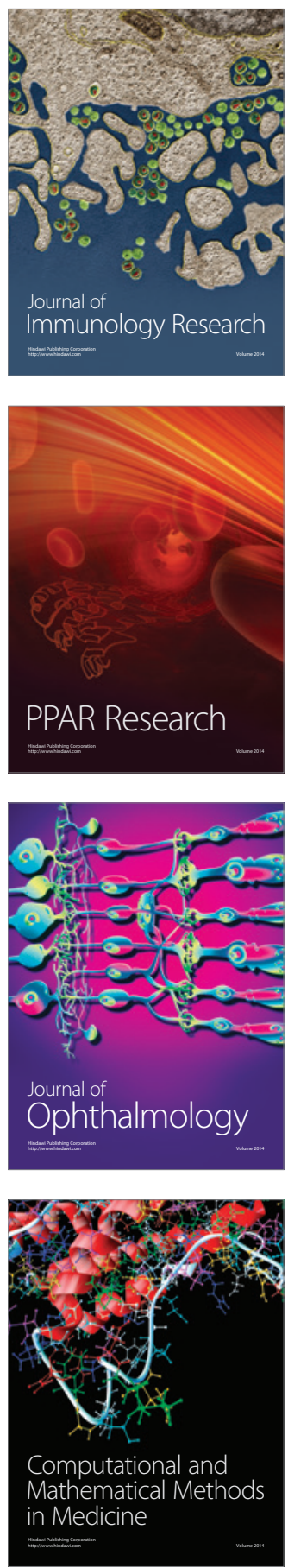

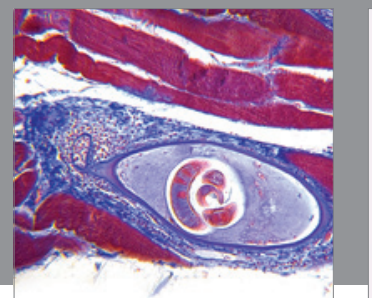

Gastroenterology

Research and Practice
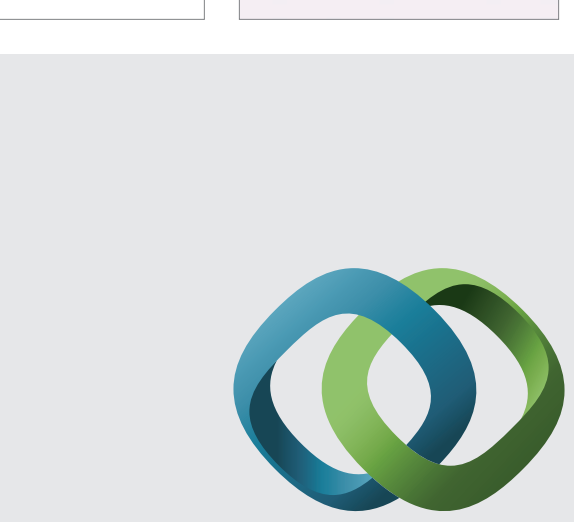

\section{Hindawi}

Submit your manuscripts at

http://www.hindawi.com
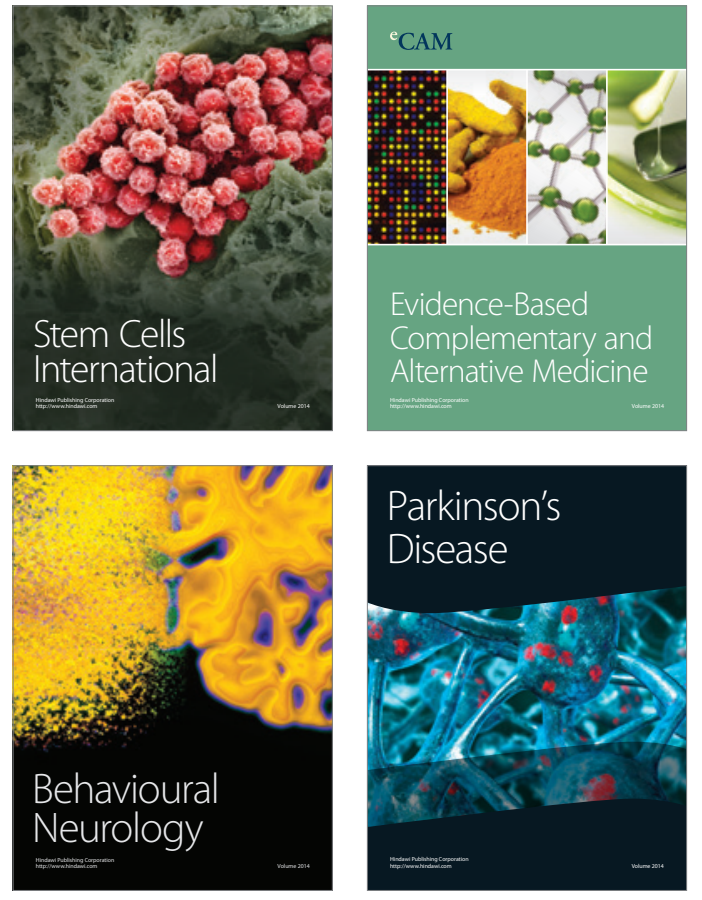
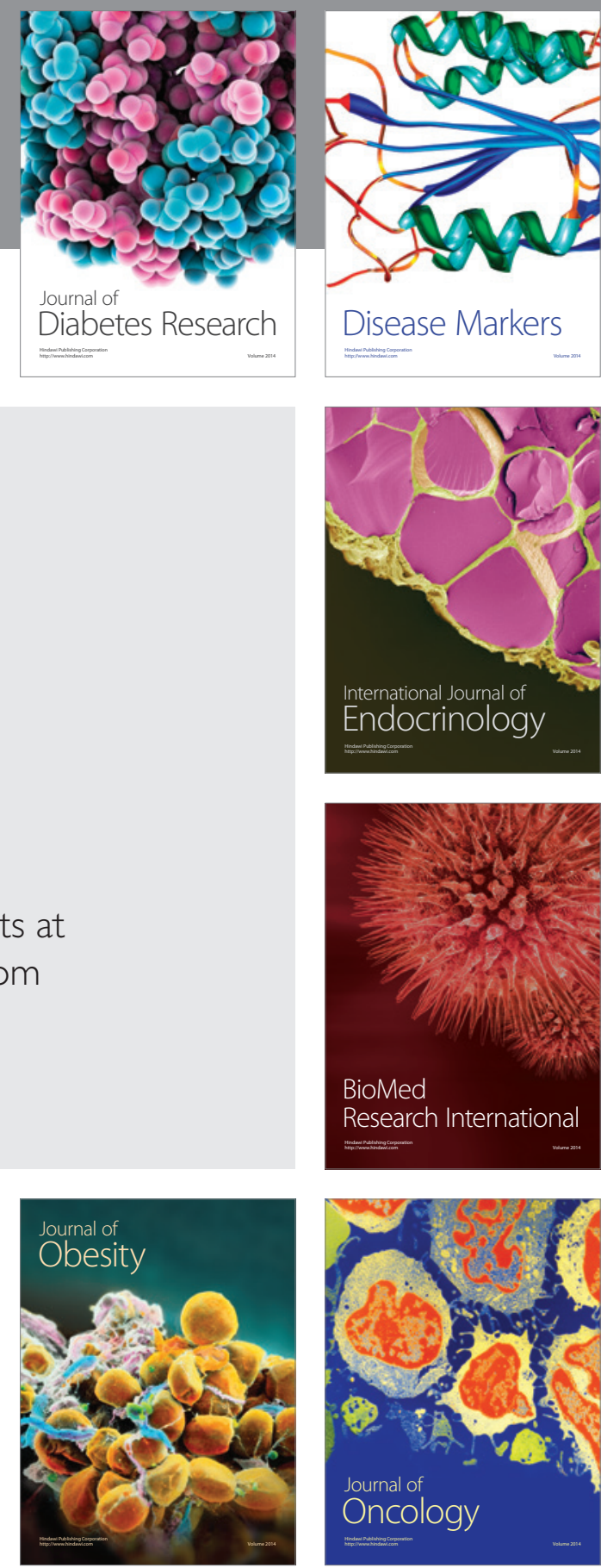

Disease Markers
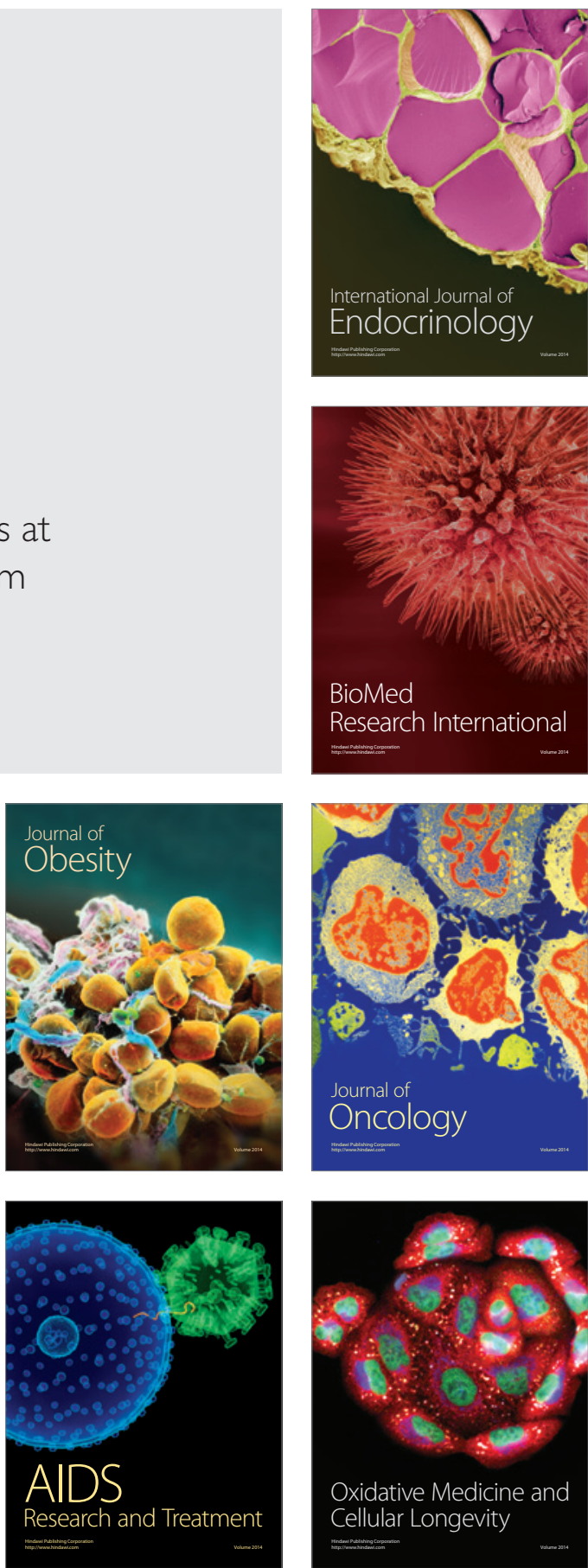